\title{
Infighting and Ideology: How Conflict Informs the Local Culture of the Chicago Dyke March
}

\author{
Amin Ghaziani • Gary Alan Fine
}

Published online: 9 September 2008

(C) Springer Science + Business Media, LLC 2008

\section{Commentary to: Int J Polit Cult Soc (2008) 20:51-67 DOI 10.1007/s10767-008-9032-x}

The data for the paper, 'Infighting and Ideology: How Conflict Informs the Local Culture of the Chicago Dyke March' were collected in 2003 by Japonica Brown-Saracino and Amin Ghaziani. The interpretations of the present article [vol. 20, pp. 51-67] are solely those of Ghaziani and Fine.

The online version of the original article can be found at http://dx.doi.org/10.1007/s10767-008-9032-x.

A. Ghaziani $(\bowtie)$

Society of Fellows, Princeton University, 10 Joseph Henry House, Princeton, NJ 08544, USA e-mail: ghaziani@princeton.edu

G. A. Fine

Department of Sociology, Northwestern University, 1810 Chicago Avenue, Evanston, IL 60208, USA e-mail: g-fine@northwestern.edu 